\title{
LOVE AND ESSENCE IN SPINOZA'S ETHICS
}

\author{
NoA LAHAV Ayalon \\ https://orcid.org/0000-0002-0764-6993 \\ University of Haifa \\ Department of Philosophy \\ Haifa \\ Israel \\ noa.lahav@mail.huji.ac.il
}

\author{
Article info \\ CDD: 149.7 \\ Received: 19.04.2021; Accepted: 21.06.2021 \\ https://doi.org/10.1590/0100-6045.2021.V44N3.NA
}

\section{Keywords}

Love

Essences

Spinoza

Affectivity

Abstract: Several questions regarding Spinoza's concept of essence have been the topic of recent scholarly debate. In this paper, I show that the connection between love, desire and essence is ubiquitous in the Ethics, as well as metaphysically and psychologically coherent; moreover, it provides the key to answer unresolved questions. Analyzing the notion of essence through Spinoza's theory of love shows that essence can be expressed in different ways, and be reflected through different objects of love. These objects of love, in turn, signify the extent to which the affected mind understands itself, God and things in the world. Each object is a different expression of the same single, unique essence of the individual, and therefore of the desire which defines them. This interpretation allows to solve some puzzles about essence, and also to establish the importance of love in Spinoza's philosophy as a whole-especially his epistemology and ethics. 
Traditionally, it has been widely accepted that Spinoza conceived of essence as something unique to each individual thing. But recently, Spinoza's concept of essence has been the topic of scholarly debate, focusing on the existence of two types of essence: particular (or unique) and universal. The debate is based on a series of textual references to essence that suggest Spinoza employed two very different uses of the term. The nature and interrelation between these two kinds of essence has been tied to the arguable distinction Spinoza makes between formal and actual existence, as well as the concept of universals and their relation to individual things.

In this paper, I show that the textual evidence does not support a dual notion of essence (whether real or conceptual). The difference between Spinoza's uses of the term essence can be aligned with the textually-coherent and relatively clear division into three kinds of knowledge. Moreover, each reference to self-conscious essence (i.e., desire), understood via the first, second or third kind of knowledge, is textually linked to a kind of love; thus I show that love, in the Ethics, is an expression of essence. Spinoza's theory of love is also based on a three-fold distinction, reliant on his theory of knowledge.

Ultimately, I present a systematic, coherent and textually viable solution to the problem of essences in the Ethics, through the prism of Spinoza's underappreciated theory of love: essence is a single, specific and unequivocal notion that has various expressions and can be perceived in different ways. There aren't two kinds or aspects of essence, but a single concept of essence that can be conceived rationally as shared or unique. The expression of essence as forms of love serves as stable ground for the construction of a theory of essence which informs Spinoza's metaphysical, psychological and ethical theories. 


\section{Essence in the Ethics}

It has been a long-standing consensus that Spinoza employs a strictly individual conception of essence; that is, each single thing has its own essence, and this essence is completely unique to $\mathrm{it}^{1}$. The idea of shared essences, which would amount to something with an uncomfortable resemblance to universals, was bluntly rejected ${ }^{2}$. But over the past decade the debate on essences has made an important shift: the existence of two types, or aspects, of essence is widely discussed ${ }^{3}$. This approach (in very general terms)

1 The complex definition of what a single thing, or individual, is for Spinoza is beyond the scope of this paper. As a rule of thumb, I refer to an individual (or singular thing) as what we perceive as such in the simplest way: a person, a dog, a chair.

2 This has been done by commentators of various interpretive approaches, such as Gilles Deleuze, Spinoza: Practical Philosophy, translated by Robert Hurley, San Francisco: City Lights Books, 1988, p. 65; Michael Della Rocca, Representation and the Mind-Body Problem in Spinoza, Oxford: Oxford University Press, 1996, pp. 8688; and Jonathan Bennett, A Study of Spinoza's Ethics. Indianapolis, IN: Hackett ,1984, 61.

${ }^{3}$ Spinoza nowhere mentions the term Della Rocca (in Della Rocca, Michael, Spinoza. New York: Routledge 2008, pp. 94-95) and Sanem Soyarslan, (in "The Distinction between Reason and Intuitive Knowledge in the Ethics, European Journal of Philosophy 24 (1), 2016) call "unique essences". They find evidence for this view in the definition of essence in Part 2, in which Spinoza posits a mutually dependent relationship between the essence of a singular thing and its existence. This is, according to Cristopher Martin ("The Framework of Essences in Spinoza's Ethics", British Journal for the History of Philosophy, 16 (3), 2008) the consensus. See also Karolina Hübner, "Spinoza on Essences, Universals, and Beings of Reason", Pasific Philosophical Quarterly, 2015; and Don Garrett, "Spinoza on the Essence of the Human Body and the Part of the

Manuscrito - Rev. Int. Fil. Campinas, v. 44, n. 3, pp. 01-41, Jul.-Sep. 2021. 
posits that there are shared as well as individual essences, which correspond to Spinoza's use of two arguably opposed terms: actual and formal essence. The metaphysical properties that pertain to each type of essence are not agreed upon by the relevant commentators, but their existence and pertinence are. Relatedly, a very important idea lies at the basis of each interpretation: there is an essence (perhaps actual) that pertains to an individual insofar as it is understood to exist for a determinate duration; and there is an essence (perhaps formal) that pertains to a mode insofar as it is part of the infinite and eternal God, understood sub specie aeternitatis.

I will now turn to the textual evidence regarding essence. Spinoza has two seemingly negating approaches to the issue which are both textually viable (hence the current debate). On the one hand, Spinoza refers to individual essence as a human beings' specific 'nature', or unique governing characteristics; and on the other hand, he posits the existence

Mind that is Eternal", in A Cambridge Companion to Spinoza's Ethics, ed. by Olli Koistinen, Cambridge, 2009. A major problem that emerges in the debate over the implication of positing a shared essence is that there is some sort of separately existing object which is an essence (that would be a Platonic, transcendental reading of Spinoza). For examples of these readings, see Valterri Viljanen, “Spinoza's Essentialist Model of Causation", Inquiry 54 (4), 2008; and Charles Jarrett, "Spinoza's Distinction between Essence and Existence", Iyyun 50, 2001. Both of these readings employ a comparison to Suarez and his theory of essence and properties. For a critic of these readings see Mogens Laerke, "Aspects of Spinoza's theory of Essence: Formal essence, non-exisetence, and two types of actuality", in The Actual and the Possible: Modality and Metaphysics in Modern Philosophy, ed. Mark Sinclair, Oxford, 2017. In general, my reading subscribes to different ways of understanding things, and not different ways of existing.

Manuscrito - Rev. Int. Fil. Campinas, v. 44, n. 3, pp. 01-41, Jul.-Sep. 2021. 
of a 'human essence', which seems to be generally binding or universal for all humans. Spinoza defines essence in the Ethics thus:

I say that to the essence of anything belongs that which, being given, the thing is necessarily posited and which, being taken away, the thing is necessarily taken away; or that without which the thing can neither be nor be conceived, and which can neither be nor be conceived without the thing ${ }^{4} \cdot(2 \mathrm{~d} 2)$

According to this definition, which ties together the existence of the singular thing and its essence, each essence has to be unique. The notion of a shared essence, which pertains to an unlimited number of individuals, is incompatible with the demand of mutual destruction (i.e., according to the definition, when the essence is destroyed, so is the individual, and vice versa-when the individual is destroyed the essence is destroyed also). Moreover, a shared essence can be perceived without an existing, destructible object which is 'necessarily posited'; in the case of an extinct species, like a certain kind of dinosaur (a T-Rex or a triceratops), we can comprehend the shared essence despite the destruction of the thing of which it was an essence. Therefore, the definition of essence presented in Part 2 supports the unique essence interpretation, and excludes the shared essence approach. Another, related and seminal

\footnotetext{
${ }^{4}$ All translations by Edwin Curley, The Collected Works of Spinoza, Princeton: 1985. All references to the Ethics are abbreviated and state the part, axiom/definition/proposition number, and corollary/demonstration/scholium. For example, 2p12s refers to part 2, proposition 12, scholium.
}

Manuscrito - Rev. Int. Fil. Campinas, v. 44, n. 3, pp. 01-41, Jul.-Sep. 2021. 
reference to essence appears in 3p7, that reads: 'The striving by which each thing strives to persevere in its being is nothing but the actual essence of the thing'. The most obvious interpretation of this proposition is quite simply an individual's private and unique attempt to avoid destruction.

Why then are shared essences a topic of discussion at all? In the propositions which lay the groundwork for Spinoza's psychological theory, which appear as early as 2p10 and continue to be a central concern well into the discussion of specific affects in Part 3, it is stipulated that there are rules which govern human nature as a whole. $2 \mathrm{p} 10$ mentions that there is some 'form' of man, and presents essence and form as parallel concepts (with the inference that both emanate properties necessarily). The form is taken here to be quite similar to the Aristotelean concept, which implies universality (see also Spinoza's mention of 'our nature', nostra natura, in 4p31d).

This idea appears also in $4 \mathrm{p} 35 \mathrm{~d}$, where Spinoza states that in acting in accordance with reason, people 'do only those things which are good for human nature, and hence, for each man'. This commonality implies a shared nature, which is synonymous, as I will show below, with essence ${ }^{5}$. In $1 \mathrm{p} 8 \mathrm{~s} 2$, concerned with the metaphysical disparities between essence and existence, Spinoza explains that the ceasing of existence of specific human individuals does not entail the destruction of human essence itself-that is, essence pertains to an unlimited and unspecified number of individuals. Moreover, it is shared by them. The existence of the essence persists with the destruction of specific humans,

\footnotetext{
5 This is a thematic as well as semantic equivalence, which appears most clearly in $1 \mathrm{p} 36 \mathrm{~d}, 3 \mathrm{p} 57 \mathrm{~s}, 4 \mathrm{~d} 8,4 \mathrm{p} 19 \mathrm{~d}, 4 \mathrm{p} 33 \mathrm{~d}$. In Latin, the terms 'nature' and 'essence' are connected with sive/seu.
} 
arguably redefining the relationship between essence and destruction presented in $2 \mathrm{~d} 2$.

Spinoza uses both the essence of triangles and humans as examples of what can be called 'species-essence' in 1p8s2. The definition of triangles and humans do not dictate that a certain number of individuals who manifest that essence exist; the definition of a human, and therefore his or her essence, is somehow independent of their specific existence ${ }^{6}$. Similarly, in $1 \mathrm{p} 17 \mathrm{~s}$ Spinoza claims that with respect to humans (and all finite modes of a single kind or species), 'if the existence of one perishes, the other's existence will not thereby perish. But if the essence of one could be destroyed, and become false, the other's essence would also be destroyed'. From this statement, it can be inferred that although existence may be unique to each individual finite mode, the essence is shared-and the destruction of one specimen need not affect the existence of the essence of the whole species.

$2 \mathrm{p} 10,1 \mathrm{p} 8 \mathrm{~s} 2$ and $1 \mathrm{p} 17 \mathrm{~s}$ are textual references that allude to a universal concept of essence. Specifically, they both regard the human individual as a singular thing, whose specific existence is conceivable as non-existent, but whose nature as a certain kind of thing (i.e., as a human being) is perceived as binding and bearing great significance to its manner of existence. Moreover, this necessary aspect of existing as a certain kind of thing is fundamental to the individual's definition, in a way similar to its definition as its

${ }^{6}$ See Martin (2008), 36-7.

Manuscrito - Rev. Int. Fil. Campinas, v. 44, n. 3, pp. 01-41, Jul.-Sep. 2021. 
own unique self 7 . In any case, this universal or formal aspect of essence is shared, and not unique ${ }^{8}$.

There are also other mentions of essence in the Ethics, especially as the text gets more and more centred on the human experience. In 3p57 we find a somewhat different concept of essence. The proposition reads: 'Each affect of each individual differs from the affect of another as much as the essence of the one from the essence of the other.' The demonstration of this proposition reiterates the point:

All the affects are related to desire, joy, or sadness, as the definitions we have given of them show. But desire is the very nature, or essence, of each [individual] ... Therefore, the desire of each individual differs from the desire of another as much as the nature, or essence, of the one differs from the essence of the other. (my emphasis)

And the scholium reads:

Therefore, though each individual lives content with his own nature, by which he is constituted, and is glad of it, nevertheless that life with which each one is content, and that gladness, are nothing but the idea, or soul, of the

7 This is not the only thing fundamental to the individual's definition-since Spinoza is a strict necessitarian (see 1p29), the human "form" or nature of the individual is as necessary as their other features, which vary from specimen to specimen in the species.

${ }^{8}$ Mentions of a universal essence can also be found in 4p36d\&s, 4p35d, 4pref II/208, among others which explicitly reference the existence of a "human nature".

Manuscrito - Rev. Int. Fil. Campinas, v. 44, n. 3, pp. 01-41, Jul.-Sep. 2021. 
individual. And so the gladness of the one differs in nature from the gladness of the other as much as the essence of the one differs from the essence of the other.

The conclusion of the scholium notes that there is significant difference between the gladness of the drunk and that of the philosopher. Here we find, it seems, a different approach to that of $4 \mathrm{p} 35$ (which defined human essence or nature as rational, and necessarily useful for perseverance in being): different people, who present different behaviors, have different essences. In one sense it is a return to the concept of individual essence presented in the original definition $(2 \mathrm{~d} 2)$; in another sense, it presents essences as classifiable (according to personal proclivities).

Spinoza's use of the examples of a drunkard and a philosopher posits another problem. The central difference between the behaviors of both individuals is that the former behaves in a way that can be labeled as 'self-destructive', and the latter does the opposite. But self-destruction is not a viable notion in Spinozistic psychology (or indeed, in his metaphysics). As clearly stated in 3p4: 'No thing can be destroyed except through an external cause'? .

It is easy to dismiss Spinoza's use of the word 'essence' in the demonstration and scholium of $3 \mathrm{p} 57$ and argue that since both the drunk and the philosopher necessarily aim to

\footnotetext{
${ }^{9}$ It is interesting to note that $3 \mathrm{p} 4 \mathrm{~d}$ attributes the impossibility of self-destruction to the definition of essence: "This proposition is evident through itself. For the definition of any thing affirms, and does not deny, the thing's essence, or it posits the thing's essence, and does not take it away. So while we attend only to the thing itself, and not to external causes, we shall not be able to find anything in it which can destroy it, q.e.d."
} 
persevere in being the link between essence and behavior (or desire) there is not viable. It cannot be that Spinoza attributes the drunk's desire for alcohol to his essence. It is his lack of power to act according to his essence which leads him to behave as he does. This is, of course, basically true; the lack of power with relation to the external cause is the reason for the person's destruction. But it is necessary to attend to the metaphysical, definitive reason why essence and desire are necessarily linked: according to $3 \mathrm{p} 7$, essence is striving to persevere in being; striving to persevere in being is also defined as appetite (3p9s); appetite and consciousness is desire $(3 \mathrm{p} 9 \mathrm{~s})$. Therefore, desire is essence together with consciousness of essence. Each and every desire is a manifestation of essence, expressing various degrees of consciousness $^{10}$. And since, in this case, consciousness can be regarded as a form of epistemic awareness or knowledge ${ }^{11}$, desires are manifestations of essence which are differentiated by degrees and classifiable into the three kinds of knowledge.

This is one reason why the central theme of the current debate on essences, based on a division into two kinds of essence (and not on three kinds), is inherently problematic. Another reason is that the formal-actual distinction, insofar as it implies some sort of potential-actual distinction ${ }^{12}$, is

\footnotetext{
${ }^{10}$ I will address the specific connection between desire and love at length below.

11 The issue of consciousness per se is far too complicated to address in the scope of this paper, and is still a contested issue in the literature. I will therefore use the term conscious exclusively in reference to mental awareness, and I will not assume it to be unique to humans (if it is indeed so).

12 See especially Hubner (2015), Martin (2008), and Garrett (2009). For an illuminating discussion on the related objective-formal
} 
incompatible with Spinoza's general metaphysics. Since all potentiality is also contingency, and contingency is a fallacy of the imagination (2p44), any form of potential-actual distinction is not viable. Moreover, the formal-actual distinction is ruled out by Spinoza himself in 5p29s:

We conceive things as actual in two ways: either insofar as we conceive them to exist in relation to a certain time and place, or insofar as we conceive them to be contained in God and to follow from the necessity of the divine nature. But the things we conceive in this second way as true, or real, we conceive under a species of eternity, and their ideas involve the eternal and infinite essence of God (as we have shown in $2 \mathrm{p} 45$ and $\mathrm{p} 45 \mathrm{~s})$.

As we can see from this passage, the modification 'actual' is expressly used by Spinoza to denote both imaginative (sub specie durationis) and rational perception of a particular thing. Therefore, 'actual' cannot mean existing in duration, as opposed to being perceived formally as an idea which is understood actively through the attribute of Thought alone. This latter form of understanding, which amounts to a rational understanding of an idea, is also considered to be of 'actual' existence according to the passage quoted above. Therefore, whether the actual-formal distinction is used to argue for two kinds of essence, or two aspects of essence ${ }^{13}$, is

distinction in Spinoza, its Cartesian legacy, and various exegetic problems, see Elahanan Yakira, Spinoza: The Case for Philosophy (Cambridge: Cambridge University Press, 2015), 126-155.

${ }^{13}$ Laerke (2017).

Manuscrito - Rev. Int. Fil. Campinas, v. 44, n. 3, pp. 01-41, Jul.-Sep. 2021. 
irrelevant. These interpretations rely on a distinction which is unclear in Spinoza, or worse, specifically flagged as misleading and requiring clarification (as evident in 5p29s) in a way that undermines their relevance altogether.

But there is a specific context in which Spinoza's various mentions of essence can be framed coherently - the ethical context. Every time the notion of essence is evoked, Spinoza is making a point which is especially relevant to his concept of naturalistic morality (i.e., the way in which ethical understanding manifests in behavior, in accordance with the necessary and determined nature of the mind and the world). When it is identified with striving to persevere in being, it highlights the way in which each individual thing strives, according to its ability and nature, to thrive. For the human being, this is ideally a moral, intellectual life imbued with contemplation and friendship. And in less ideal settings, in a world riddled with competing life forces, passions and clashing desires, this is an essence as described in 3p57s: of an alcoholic or a philosopher, differing in natures and differing in gladness. In all scenarios, and whether the term essence seems to be of unique or universal essences, essence is a force that engenders behavior in the world and can lead to happiness and blessedness or unhappiness and wretchedness.

In the following sections, I will present a new interpretation of Spinoza's theory of essence, stemming from Spinoza's ethical theory, which stands on two legs: Spinoza's famous tripartite theory of knowledge, and his much less discussed theory of love. The epistemological division into imagination, rational common notions and intuitive knowledge serves as the basis for an interpretation of essence that does not rely on a division into two kinds or aspects of essence; it explains the differences in the presentation of essence throughout the Ethics as different 
perceptions of a single essence, via the first, second or third kind of knowledge. When essence is understood rationally, it is perceived either as a species essence (through the second kind of knowledge) or individually through its immanent cause as a portion of God (via the third kind of knowledge). The mixed, semi-rational references to essence, which are explained partly through passions and external forces (such as the reference mentioned above in $3 \mathrm{p} 57 \mathrm{~s}$, which discusses the 'essence of the drunk') are linked to the imagination or the first kind of knowledge.

I argue that the best way to clarify these three references to essence is through a discussion of Spinoza's theory of love. In keeping with the general aim of providing an ethical interpretation of essence, the issue of love becomes especially pertinent to the discussion: Spinoza singles out love as the most important value-generating emotion; therefore, as well as being a catalyst for behavior or action, love represents the virtuousness of each and every significant decision made in one's lifetime.

[...] it should be noted that sickness of the mind and misfortunes take their origin especially from too much love toward a thing which is liable to many variations and which we can never fully possess. For no one is disturbed or anxious concerning anything unless he loves it, nor do wrongs, suspicions, and enmities arise except from love for a thing which no one can really fully possess.

From what we have said, we easily conceive what clear and distinct knowledge-and especially that third kind of knowledge (see $2 \mathrm{p} 47 \mathrm{~s}$ ), whose foundation is the knowledge of 
God himself - can accomplish against the affects. Insofar as the affects are passions, if clear and distinct knowledge does not absolutely remove them (see p3 and p4s), at least it brings it about that they constitute the smallest part of the mind (see p14). And then it begets a love toward a thing immutable and eternal (see p15), which we really fully possess (see $2 \mathrm{p} 45$ ), and with therefore cannot be tainted by any of the vices which are in ordinary love, but can always be greater and greater (by p15), and occupy the greatest part of the mind (by p16), and affect it extensively. (5p20s)

As we see from this passage, the ethical significance of love is two-fold: it is the strongest indicator, for the agent, of what is good; and its behavioral manifestations indicate the moral standing of a specific agent (the more rational the love-object, the more morally-advanced the individual). In addition, reflective engagement with an individual's love-life, so to speak, is the most therapeutically efficient activity one can hope for.

Simply put, my argument for interpreting essence through its connection to love is as follows: the dichotomous division of essence into two kinds is inconsistent with the text (either according to the objective-formal distinction or the actual-formal distinction). The difference between Spinoza's use of the term essence, though, can be aligned with the textually-coherent and relatively clear division into three kinds of knowledge (assuming that conscious essence, as shown above, is desire). Each reference to self-conscious essence (i.e., desire), understood via the first, second or third kind of knowledge, is textually linked to a kind of love. The final stage of the argument (i.e., connecting the three kinds 
of understanding essence with three kinds of love), depends on showing that Spinoza's theory of love is indeed based on a three-fold distinction, that is based on his theory of knowledge ${ }^{14}$. Therefore, in the following sections I will briefly present Spinoza's theory of love. Through the analysis of love, which is discussed at various points in the Ethics and might seem equivocal (like essence) due to its very broad use, I will show that essence is a metaphysical concept which is expressed differently in different contexts, while retaining its original definition.

\section{Spinoza's concept of love}

Spinoza defines love in 3p13s: 'love is nothing but joy with the accompanying idea of an external cause'. Love is an affect; affects are changes in the power of the body and mind. Joy is an increase of power to act, sadness a decrease in power. Of the three primary affects (desire, joy and sadness) ${ }^{15}$, love is identified as a form of joy (laetitia), despite

\footnotetext{
14 Of the few commentators who have discussed Spinoza's theory of love, not all have adhered to the division into three kinds of love (see for example Hasana Sharp, "Love and Possession: Towards a Political Economy of Ethics 5", NASS Monograph 14 (2009); and Amelie O. Rorty, "Spinoza on the Pathos of Idolatrous Love and the Hilarity of True Love" in Feminist Interpretations of Benedict Spinoza, ed. Moira Gatens (University Park, Pa.: Pennsylvania State University Press, 2009), who argue for two kinds of love, i.e, rational and irrational or mad and wise). An important, recent proponent of this view is Andrew Youpa, The Ethics of Joy: Spinoza on the Empowered Life (Oxford: Oxford University Press, 2020).

${ }^{15}$ For a general discussion of Spinoza's psychology and his theory of the affects, see Michael Della Rocca, "Spinoza's Metaphysical Psychology," in The Cambridge Companion to Spinoza, Don Garrett
} 
the fact that love (amor) and desire (cupiditas) are intuitively or common-sensibly linked. The definition of love, as joy with an external cause, is sensitive to its context of Part 3 ('On the Affects')—it explains a specific kind of love, namely, passionate love, which is directed toward external objects. Passionate love is infinitely varied; it has as many iterations as there are objects and minds (3p56).

Spinoza's definition of love just barely distinguishes it from joy proper. The definition is indeed so slightly removed from joy (via the modification of 'the accompanying idea of an external cause') that it is arguably one and the same. Love can only ever be considered harmful or bad insofar as it is related to an external object (4p44d). Although love can be excessive, and then cause the individual to do harmful, irrational things, love in and of itself is necessarily joyous and therefore good. Desire and love (just like desire and joy) go hand in hand most importantly because it is of the essential nature of the individual to strive to persevere in being (according to 3p7, it actually is the essence of the individual to strive to persevere in being) - and in order to do so one strives to be empowered (i.e., one strives to empower themselves). The more powerful the individual the harder it is for them to be destroyed; and the more joyous the individual the more powerful they are. The problems with love arise when its object is not rationally understood, and

(ed.), Cambridge: Cambridge University Press, 1996; Susan James, "Spinoza the Stoic," in The Rise of Modern Pbilosophy, Tom Sorell (ed.), Oxford: Clarendon Press, 1993; Michael LeBuffe, "The Anatomy of the Passions," in The Cambridge Companion to Spinoza's, Ethics, Olli Koistinen (ed.), Cambridge: Cambridge University Press, 2009; Eugene Marshall, The Spiritual Automaton: Spinoza's Science of the Mind, Oxford: Oxford University Press, 2014. 
then the desire, behaviors, and images which accompany love can have weakening or dangerous results.

It is important to situate love in the broad psychological scheme of human affects, since it derives its most important traits from Spinoza's general metaphysical psychology (as he writes in the preface to Part 3, there are neither exceptions nor freedoms in our emotional lives-human actions and appetites ought to be understood just like 'lines, planes and bodies'). Spinoza's three primary affects are divided into two groups: desire is in its own category (a motion or drive); while joy and sadness two opposites which make up another (defined as transitions of the mind to greater or lesser perfection). As affects, they are all configurations of the complex idea which is the human mind; an idea of its object, the body. Desire is a configuration which leads to certain behaviors: it drives the mind and the body to interact with external objects in certain ways. This drive is governed by certain laws, which are similar to all other laws which govern the modes of God or Nature-desire is nothing but the power of the individual, insofar as it is a manifestation or a portion of God's power. Joy and sadness are configurations of the mind which signal the enhancement or diminishment of its power, respectively. When the mind is in a joyful configuration, and so, when it loves, it is more perfect and therefore more powerful. When the mind is saddened, the ideas it is made up of are in a worse configuration, and it is less powerful. A loving mind is better at persevering in being, a hateful mind is worse at it.

Since Spinoza does not identify love and desire, it is important to clarify their similarities and differences ${ }^{16}$.

${ }^{16}$ I would like to thank two anonymous reviewers for raising concerns regarding the relation between love and desire. A specific worry centered around positing a necessary link between love and desire, and noted the ability to love something without desiring it

Manuscrito - Rev. Int. Fil. Campinas, v. 44, n. 3, pp. 01-41, Jul.-Sep. 2021. 
Although love is not classified directly as a primary affect, its near-identity with joy makes its status a bit confusing. According to 3p13s, love is joy accompanied by an idea; the definition begs the question-what would joy be, unaccompanied by an idea? Can we conceive joy that is completely unrelated to an idea (external or innate)? Speaking of a transition of power in an individual (i.e., the definition of joy) without an assumption of its having a certain cause (an accompanying idea) is pragmatically meaningless in Spinoza's system due to the principle of sufficient reason $(1 \mathrm{p} 28)$. That is, according to my interpretation joy and love are identical, but the former is regarded abstractly, as an enhancement of the mind, while the latter is regarded in a more practical manner, as joy with a cause (as all joy, like all affections, must be).

Love, insofar as it is a passion, is concerned with separate, interacting entities: it is the result of clashing life forces, which are drawn and repelled from one another. Therefore, desire is identified with the individual herself (an identification congruent with the definition of the individual's essence as desire), while passionate love is a certain effect an external object may have on the individual.

(as is the case with something I love that I had not previously known); and desiring something without loving it (hope and praise were given as examples of forms of laetitia that give rise to desire without love). In the former case, some form of desire must necessarily accompany awareness of a beloved thing - even if this desire is only to continue being aware of the thing. Seeing a painting that brings me joy, for example, is expressed as both my love of the painting and my desire to continue seeing it. In the latter case, I think Spinoza would define hope and praise as forms of desire that express love of self-in the first case, wanting the best for oneself in the future, and in the second case, enjoying selfesteem or self-love through praise. 
Unlike desire, which is in a sense absolute, passionate love is first and foremost the result of a relation between subject and object.

Passionate love, an affect which is the result of signs, sensory representation, recollections and imaginings, is both powerful and inconstant. As Spinoza mentions in 2p16c2 ${ }^{17}$, 'the ideas which we have of external bodies indicate the condition of our own body more than the nature of external bodies.' In virtue of the dual, parallel manifestation of the body and mind in the attributes of Extension and Thought, passionate love is also more indicative of the state of the mind than of the beloved object. That is, the objects of my affection tell me more about myself than about the objects themselves; the fact that I love something is indicative of me, more than it is of the object of affection.

The connection between love and desire is emphasized in their shared use in the group of definitions near the end of the Definitions of the Affects of Part 3: 'Gluttony is an immoderate desire for and love of eating'; 'Drunkenness is an immoderate desire for and love of drinking'; 'Greed is an immoderate desire for and love of wealth'; 'Lust is also a desire for and love of joining one body to another' (Def. 458 ). The difference between love and desire can be regarded as a perspectival one: love is a concept which is defined by the object of affection; desire is defined by the subject (i.e., the agent). For each object of love we have a different form of desire. Each desire, in turn, is a strong indicator for the condition in which the mind of the subject is, and, in a way, for the nature of the mind itself (3p56s). Greed, for example, is defined by identifying money as the object of excessive affection. But money is not a thing which is rational to desire

17 This idea is reiterated several times, especially in 2 p23 ff., 3 p14, and $3 \mathrm{p} 51$. 
excessively; its relentless pursuit can result in serious harm to the individual. I will return to this issue below.

Love as it is experienced in life (i.e., under the aspect of duration) is not always a passion. That is, passionate love, although discussed at great length in Part 3, is not the only kind of love there is. Spinoza refers to two other kinds of love, both rational and related to the mind insofar as is acts (and not insofar as it is acted on, as is the case with passionate love). The first is friendship, or love of neighbour; the second is love of God, which is itself divided into two kinds - generic and intellectual. These two kinds of rational love are congruent with two kinds of rational knowledge, ratio and Scientia intuitive (2p40s2).

Friendship is regarded as a form of love, or an outcome of love, through the definition of nobility which appears in $3 \mathrm{p} 59 \mathrm{~s}$ (the proposition itself is concerned with the actions, rather than the passions, of the mind): 'By nobility I understand the desire by which each one strives, solely from the dictate of reason, to aid other men and join them to him in friendship'; coupled with 4p46, in which love and nobility are straightforwardly equated ${ }^{18}$.

As examples of nobility, Spinoza names courtesy and mercy. These actions represent understanding, or perceiving adequately, the relation between the mind and body of the individual and other individuals. It is the human being's drive, through reason, to connect with her peers and create friendships. This is the basis of morality and true piety; moreover, it is defined by Spinoza as the foundation of the state (4p37). Since there is so much in common between the thinking human mind and other human minds outside of it,

\footnotetext{
18 "He who lives according to the guidance of reason strives. As far as he can, to repay the other's hate, anger, and disdain toward him, with love, or nobility".
}

Manuscrito - Rev. Int. Fil. Campinas, v. 44, n. 3, pp. 01-41, Jul.-Sep. 2021. 
and since these commonalities make other humans the most influential and important factors in a human life, this active affect is of the utmost importance. Spinoza explains its importance through his detailed discussion of the challenges of human existence.

A major theme of Part 4 is Spinoza's depiction of human life as an ongoing series of trials and tribulations. He reiterates and emphasizes the finitude and limitations of man's power ${ }^{19}$, and consequently the difficulty in overcoming harmful passions. The deleteriousness of excessive desire, and the ease with which reason is overcome (Spinoza quotes Ovid's Medea in 4p17s, the classical reference to weakness of will), make the good life and peace of mind seem unattainable. But in the scholium to $4 \mathrm{p} 18$, he makes a point of pivoting from this line of thought:

With these few words I have explained the cause of man's lack of power and inconstancy, and why men do not observe the precepts of reason. Now it remains for me to show what reason prescribes to us, which affects agree with the rules of human reason, and which, on the other hand, are contrary to those rules.

Spinoza gives in very broad strokes ('before I begin to demonstrate these things in our cumbersome geometric order'), the thrust of his argument: reason, as a part of Nature

19 This is first presented in the only axion to Part 4 as a general rule: "There is no singular thing in Nature than which there is not another more powerful and stronger. Whatever one is given, there is another more powerful by which the first can be destroyed." This issue is revisited in 4pp2-3, 4p4d\&c, 4p6, 4p15, 4p17, among others. 
itself, dictates that all humans love themselves, seek their own advantage and desire what enhances their power and prospects of survival. Since virtue is acting according to this striving to persevere in being, insofar as it is a human's nature or essence itself, a virtuous and happy person is one that is able to preserve his or her being, and happiness consists in aiding this goal. But since humans are singular, limited things, living in a world with an infinite number of external forces which surpass their own, help is needed. Spinoza's theory regarding what we can do to survive and even flourish in life begins with creating friendships. Moreover, he claims that the most important ingredient of a happy, healthy life in which external powers are overcome, is none other than friendship ${ }^{20}$ :

There are, therefore, many things outside us which are useful to us, and on that account to be sought. Of these, we can think of none more excellent that those which agree entirely with our nature. For if, for example, two individuals

20 The most substantial reference to this issue in Spinoza is to be found in Jeanette Bicknell's 'An Overlooked Aspect of Love in Spinoza's "Ethics"' (1998). Bicknell defines friendship, or 'selfdetermined love' for others as the most rewarding of human relationships. I disagree with Bicknell in her assessment that friendship is based on adequate knowledge of the self and of the loved one - an adequate knowledge of a particular thing is defined as the third, and not the second kind of knowledge (with relates to common properties). As I show here, the correct way to understand Spinoza's account of love (in its various forms) is through his theory of knowledge. Nevertheless, I find Bicknell's article to be illuminating and relevant; more than twenty years later, this subject is still largely 'overlooked'. A more recent addition is found in Frank Lucash, "Spinoza on Friendship", Philosophia 40 (2), 2012. 
of entirely the same nature are joined to one another, they compose an individual twice as powerful as each one. To man, then, there is nothing more useful than man. (my emphasis)

The best way to flourish in life and become more virtuous and powerful is to bond with others in friendship. In Spinoza's formulation, friendship is a bond or connection between equals. Spinoza ties friendship together with the dictates of reason in almost all of its mentions (3p59, 4p35, $4 \mathrm{p} 37,4 \mathrm{p} 70)$. True friendship, for Spinoza, is not a human connection that has a passionate basis; on the contrary, passions are what make men disagree in nature, and therefore prevent them from becoming friends (4p32, $4 \mathrm{pp} 34-5)$. In a way, the friend is not an external cause or object, but an appreciation or understanding of the common properties shared by two minds, which bond them and makes the minds as one. The value the person sees in her friend is not of a contingent, idiosyncratic trait, but a recognition (based on reason) of the common properties they share. Moreover, the love toward a friend is an affect which stems from rational thought and freedom of mind, and therefore is beneficial, empowering, and cannot be excessive (4p37, 4p71d). For Spinoza, friendship is necessarily tied to reason because its very nature as a relationship based on equal community cannot pertain to any other aspect of the human mind, other than reason: 'Only insofar as men live according to the guidance of reason, must they always agree in nature' (4p35, my emphasis).

The ideal friendship is described in $4 \mathrm{p} 71$, and again invokes the affect of love. This proposition, which argues that thankfulness is a mark of freedom, powerfulness, and equality between individuals, addresses the thorny issue of gratitude, favors and utility between friends. Spinoza was 
probably familiar with the famous Aristotelian (and Maimonidean) division of friendships into utility, pleasure and virtue, and he consciously conflated the three kinds. In the demonstration to this proposition we find a clear connection between all aspects of friendship, and love: 'Only free men are very useful to one another, are joined to one another by the closest bond of friendship (by p35 and $\mathrm{p} 35 \mathrm{c} 1$ ), and strive to benefit one another with equal eagerness for love (by p37)'. The free man, that is, the rational man (by 4p66s), does not differentiate between utility, pleasure and virtue, because in his constitution they are one and the same: there is nothing more useful or pleasurable to human nature than acting according to its virtue-which is understanding ${ }^{21}$.

${ }^{21}$ There is a striking resemblance between Spinoza's and Aristotle's presentation of the tension and co-dependence between politicalsocial life and autarkic contemplation. For an awe-inspiring exposition of the famous issue in Aristotle, see Richard Kraut, Aristotle on the Human Good, Princeton, 1991. Spinoza's analysis of freedom and blessedness (what Aristotle what call the good life, or the telos of a human being) is indeed very similar to Aristotle: on the one hand, real freedom must be self-sufficient; on the other hand, self-sufficiency, for human beings, is an impossibility in our durational experience. Spinoza's metaphysics of causality, as well as his division of kinds of knowledge, allows him to offer a consistent solution to this problem. Aristotle, on the other hand, leaves the contradiction in place to some extent, and by doing so reflects the philosopher's experience with an unmatched authenticity. One of the main similarities between the two thinkers is that ultimately, it is unclear to the readers whether the contemplative ideal, or the exemplar of the Free Man, is in fact attainable; and if so, whether its attainment is at all enduring. On this issue in Spinoza, see Steven Nadler, "On Spinoza's 'Free Man'", Journal of the American Pbilosophical Association, vol 1 (1), 2015; Matthew Kisner "Reconsidering Spinoza's Free Man: The 
There is love shared between the virtuous, since love is joy and the virtuous are joyous; and this love is the love of friends. True friends, then, have no issue with ingratitude or envy, because the only real favors they can grant one another do not impoverish the one and enrich the other, but enrich both equally and simultaneously. Through the friends' joint understanding of their common properties and the sharing of knowledge, they become happier and closer, and this makes them very grateful to one another. In order to avoid further misunderstandings, Spinoza actually distinguishes in the scholium of the proposition between true utility (solely rational knowledge) and false or inadequately perceived utility, such as money or other material favors. Accepting a favor such as money, for Spinoza, does not merit the thankfulness generated when something of true value (i.e., knowledge) is shared; this is best understood as a 'business transaction or an entrapment' (4p71s). Therefore, these benefactors, even if they mean well, are not friends to the utmost degree, since they are not equal to one another and the benefits they confer are not intellectual; friendship, as stated in the proposition, is reserved to the free alone (insofar as they are free, of course 22 ).

Model of Human Nature", Oxford Studies in Early Modern Philosophy (5), 2010; and Andrew Youpa, "Spinoza's Model of Human Nature", Journal of the History of Philosophy, vol. 48 (1), 2010.

22 That is not to say that the free man should callously reject all favors and benefits (see the rest of $4 \mathrm{p} 71 \mathrm{~s}$ quoted above and also 4p70, especially 4p70s). See Daniel Garber, "Dr. Fischelson's Dilemma: Spinoza on Freedom and Sociability", in Spinoza on Reason and the "Free Man," ed. Yirmiyahu Yovel and Gideon Segal, New York: Little Room Press, 1994. Garber addresses the apparent contradiction between a free man being perfectly autarkic and rational and at the same time "perfectly sociable" $(184,191)$. Garber claims that real freedom denies sociability, and yet Spinoza 
The final kind of love to be discussed is love of God. In Part 5, Spinoza presents two kinds of love of God: one is unqualified (or generic, amor der), and one is the famous intellectual love of God (amor dei intellectualis). The former is defined in 5p15, which reads: 'He who understands himself and his affects clearly and distinctly loves God, and does so the more, the more he understands himself and his affects.' This definition is the outcome of an argument regarding the destruction of the passions that is laid out in the propositions of Part 5 up to that point (5pp1-14). In a nutshell, Spinoza claims that the mind, while acting in accordance with its nature (i.e., when it rationally understands ideas), has the power to overcome, or destroy, the passions. This destruction is achieved by a separation of the mind's affection from the external cause of the passion, through an understanding of the affection as a necessary outcome of a series of causes and effects that involve the mind and the

repeatedly commends it. An attempt to reconcile the two statements, which ultimately is not deemed unproblematic, is addressing the free man as an unattainable model (i.e., an exemplar). I think Garber's contradiction can be resolved through an appreciation of the two kinds of adequate ideas Spinoza allows: the rational ideas of common notions (which allow varied finite things and transitive causal chains) and the intuitive (and rational) ideas of the essences of things (which allow only God as proximate cause). This is suggested in Garber's quote of 4p68s (202), but is not interpreted by him thus. Garber's notion of rationality is singular, and so is the differentiation between adequate and inadequate ideas. But it is important to note that Spinoza has two alternative forms of adequate ideas, and not just the one. Sociability, then, can be conceived as rational insofar as other people are understood via the second kind of knowledge, and autarkic contemplation is the rational goal of understanding via the third kind of knowledge. 
external cause ${ }^{23}$. This necessity, or comprehension of the affect as a result of determined laws, makes the mind impervious to the damaging effect of the affect; it takes the sting out of the passion. No longer is the passion something that is thrust upon the mind from outside, something to be suffered. It becomes something that pertains to the mind due to its own nature: the mind now understands the affect as something that couldn't have been otherwise, as something that expresses its own nature, much more than that of the external cause (if at all).

Since this destruction of the passions is inherently linked to understanding the affect of the mind and the external cause as parts of the whole of Nature, operating according

${ }^{23}$ For a different interpretation, see Colin Marshall, "Spinoza on Destroying the Passions with Reason", Philosophy and Phenomenological Research 85 (1), 2012. Marshall gives a clear and illuminating presentation of this issue, and it is related, albeit different, from my own reading of Spinoza's theory. Marshall acknowledges that philosophizing is the mental activity Spinoza points at when he discusses destroying the passions, and also states that 'this activity necessarily draws attention away from the particulars of our surroundings' (153), but doesn't define it, as I argue here, as a progression through the three kinds of knowledge. Marshall sees philosophizing about the passions as 'killing the mood', and likens it to a mental distraction; but I don't think this gets to the core of Spinoza's meaning. What Spinoza is aiming at is direct engagement, which, when done well and correctly, creates the only sort of change we are capable of making: change in our understanding of the object of thought. One of the major disadvantages of Marshall's reading, and the main way in which it differs from mine, is the lack of relevance or continuity to the second half of Part 5, in which Spinoza uses his discussion of the movement from passivity to activity and the destruction of the passions as the basis for attaining the third kind of knowledge and experiencing the intellectual love of God.

Manuscrito - Rev. Int. Fil. Campinas, v. 44, n. 3, pp. 01-41, Jul.-Sep. 2021. 
to its necessity, and since for Spinoza God is Naturedestroying the passions means understanding and thinking of God. The empowerment that comes with this understanding, the enhancement of action and diminishment of passivity, brings joy (in a way, the empowerment or 'passage into a greater perfection' is itself joy, as per 3p11). And according to the definition of love, joy with the accompanying idea of God is indeed love of God.

The intellectual love of God relates to a different mode of understanding. It is defined quite late in Part 5:

From the third kind of knowledge, there necessarily arises an intellectual love of God. For from this kind of knowledge there arises (by p32) joy, accompanied by the idea of God as its cause, that is (by DefoAff VI), love of God, not insofar as we imagine him as present (by p29), but insofar as we understand God to be eternal. And this is what I call intellectual love of God" (5p32c).

The mode of understanding which is the third kind of knowledge (Scientia intuitiva) is emblematic of understanding things under a species of eternity. This is why the quote above pointedly remarks on the difference between imagining God and understanding him to be eternal. Perceiving the idea of God in a way which engenders the generic love of God has to do with understanding our mind and body in relation to other minds and bodies, in an existence which has some markings of the imaginary and the aspect of duration, or transiency.

Precisely because of this relation to eternity and immutability, the intellectual love of God is unique in its relation to affectivity. Affectivity in the context of eternity is 
not really a form of change, since change implies a concept of duration. Affectivity is now reduced to a particular species of joy-one that is more of a state than an increase (or change) in power. It is important to note that understanding by the third kind of knowledge and the intellectual love of God are not one and the same, but the love is a necessary result of the knowledge. That is, intellectual love of God is the joyous, emotional result of the mind's intellectual labor at its finest-the perfection of human action.

In 5p33s, Spinoza writes 'although this love toward God has no beginning (by p33), it still has all the perfections of love, just as if it had come to be (as we have feigned in p32c)' (my emphasis). The intellectual love of God is a form of love, comparable to passionate love and rational love, but it is unique in its participation in eternity. This is Spinoza's distinction between joy and blessedness-mundane joy is a passage, a change, and it requires a concept of time. But time is of the imagination; it has no place in an understanding of eternity ${ }^{24}$ or in an idea understood via the third kind of knowledge. So although the highest joy retains the nomenclature of love, it is redefined as blessedness, a state that implies no change, and relates to the mind insofar as it is caused immanently by God.

The final proposition of the Ethics (5p42) ties together the kinds of love and the power of knowledge, summing up the prescriptive ideas of the book as a whole: 'Blessedness is not the reward of virtue, but virtue itself; nor do we enjoy it

24 As explained as early as Part 1: "By eternity I understand existence itself, insofar as it is conceived to follow necessarily from the definition alone of the eternal thing. Exp.: For such existence, like the essence of the thing, is conceived as an eternal truth, and on that account cannot be explained by duration or time, even if duration is conceived to be without beginning or end" (1d8).

Manuscrito - Rev. Int. Fil. Campinas, v. 44, n. 3, pp. 01-41, Jul.-Sep. 2021. 
because we restrain our lusts; on the contrary, because we enjoy it, we are able to restrain them.' The demonstration shows that through the joy the highest form of understanding brings, the lower form of understanding, which is emblematic of lust or 'ordinary' love, is already restrained and controllable. The scholium of $5 \mathrm{p} 42$, which concludes the book, again ties together the unwise man's susceptibility to lust as a function of his lack of knowledge, or unconsciousness of himself, and God and things; and that freedom and peace of mind consist not in abstinence, but in love-love for the right object.

\section{Love as an expression of essence}

In this final section, I will summarize the way in which love is an expression of essence, by addressing each form of love in turn. Then, I will offer resolutions to some debates on essence, made possible by the connection between essence and love.

First, I will address the issue of passive (or passionate) love as an expression of essence. When an individual is affected by love for an external object, what Spinoza refers to as passive love, they desire to possess it; this desire is informed, whether self-consciously or not, by the joy and empowerment they experience when united with the object. Joy and empowerment are themselves nothing but expressions of the individual's striving to persevere in being, or essence. The better the individual achieves being joyful and thus empowering herself, the better she will achieve perseverance. Since essence is itself this striving to persevere in being, love is its expression of the individual's essence.

In the case of passive or passionate love, the essence is expressed in a very imperfect way; the subject's essence is 
only the partial cause of the affect of love (the other cause of the affect is, of course, the external object). The desire to possess an external object is necessarily misguided and futile, since mutable things can never really be possessed (as Spinoza writes explicitly in 5p20s). Excessive, passionate love for another person, for example, can end in heartbreak for multiple reasons: the love not being reciprocated, the beloved's death, or myriad other reasons. Love for wealth or honor is not steadier or more reliable; as Spinoza writes in the Treatise on the Emendation of the Intellect, it can even have disastrous consequences and put the person in pursuit of them in great danger ${ }^{25}$. It is important to bear in mind, of course, that by the very act of desiring something, one acknowledges its value to them; so when someone loves money, it is implicit that they think it is good and useful. Their excessive love for it is irrational and misguided, and that is the passive, weak aspect of their affect-the aspect that is attributed to their lack of power, or the relational powerfulness of the external object with respect to their

\footnotetext{
25 '... all those things men ordinarily strive for, not only provide no remedy to preserve our being, but in fact hinder that preservation, often cause the destruction of those who possess them, and always cause the destruction of those who are possessed by them. There are a great many examples of people who have suffered persecution to the death on account of their wealth, or have exposed themselves to so many dangers to acquire wealth that they have at last paid the penalty for the folly with their life. Nor are there fewer examples of people who, to attain or defend honor, have suffered most miserably. And there are innumerable examples of people who have hastened their death through too much sensual pleasure' (II/5-12).
}

Manuscrito - Rev. Int. Fil. Campinas, v. 44, n. 3, pp. 01- 41, Jul.-Sep. 2021. 
mind. The same goes for lovers of honor, sensual pleasure, and any kind of external object ${ }^{26}$.

When people desire things that do not promote their real well-being, they suffer. But why, then, do they desire these things? Spinoza's answer is simple: they do not understand well; they have inadequate understanding of themselves, and God, and things. If people were to understand themselves well, as inseparable parts of Nature that operate according to certain determinate rules, they would not love things that do not truly assist their perseverance in being. Since the essence of humans' minds is to understand, the only action which is a worthwhile goal is understanding-it is the only form of behavior that constitutes action in accordance with Nature (and at the same time, virtuous action, which constitutes blessedness) ${ }^{27}$. Understanding better will allow us to love better things; thus acting according to our essence and preserving our existence all the more.

The achievement of understanding leads us to the first kind of rational love, friendship. Friendship, which is the subject's rational action which binds others to him in love, is another form of expression of his or her essence. Friendship, for Spinoza, has strong political significance: it is the

\footnotetext{
26 Spinoza is very clear that the excess of love and desire are the problem, and not the affects per se. He famously writes in in 4p45s: 'It is the part of the wise man, I say, to refresh and restore himself in moderation with pleasant food and drink, with scents, with the beauty of green plants, with decoration, music, sports, the theater, and other things of this kind, which anyone can use without injury to another'. That is, moderate pleasures from worldly things is important and beneficial.

27 This is clearly asserted in sections 1-4 of Appendix to Part 4, and repeated continuously through all of Part 5, which deals with the power of the mind or intellect over the affects.
} 
foundation of the social contract which enables the existence of the state. For Spinoza, there is nothing more pertinent for perseverance in being than being a part of society. So in the case of friendship, or love between humans which is based on their common properties and shared nature, human essence is expressed in two interconnected ways. The first is the simple sense in which striving to persevere in being (i.e., essence) is aided by friendship. The second is the fact that friendship is based on what is sometimes referred to as 'shared essences', that is, the common properties that belong to humans necessarily and constitute a 'human nature'.

By analyzing the concept of essence via love, we see that understanding things rationally, and loving objects which correspond to this understanding, do not point to the existence of shared essences. The essence of the individual is always the same, but it does have properties that are common to other individuals; these properties inform the objects of love and desire that necessarily emanate from the essence itself (which is strictly unique) ${ }^{28}$. When Spinoza is discussing the life of the individual as a social creature, or as a citizen, he addresses human essence as an idea with shared properties between individual humans. In this context, essence and 'human nature' are closely linked ${ }^{29}$. Friends, who share a rational love, agree in nature (4pp31-35); and this

\footnotetext{
${ }^{28}$ See $2 \mathrm{p} 39$.

29 As explained in the demonstration to $4 \mathrm{p} 26$ : 'The striving to preserve itself is nothing but the essence of the thing itself (by 3p7), which, insofar as it exists as it does, is conceived to have a force for persevering in existing (by 3p6) and for doing those things which necessarily follow from its given nature...'
} 
agreement in nature tracks back to their individual essences, which share properties insofar as they are human ${ }^{30}$.

Finally, the intellectual love of God presents the most desirable, virtuous expression of essence in the human mind. Reminiscent of the case of friendship, and again due to the rationality that guides this form of love, essence plays a double role in the intellectual love of God. By achieving this intellectual love, the mind performs the action which is the absolute expression of its nature or essence, (i.e., intuitive understanding); and also, the object understood is the essence of singular things (2p40s2). That is, essence plays an explanatory role in the subject's affective state as well as constituting the object of understanding.

It is beyond the scope of this paper to give a comprehensive interpretation of what it means to understand the essence of singular things (that is, to understand things via the third kind of knowledge) ${ }^{31}$.

${ }^{30} \mathrm{It}$ is interesting to note that in this cluster of propositions of Part 4, where the topic of discussion is the similarities and differences of individual human essences and the part that human nature plays in understanding them, only in $4 \mathrm{p} 33 \mathrm{~d}$ does Spinoza actually identify essence and nature: 'The nature, or [seu] essence of the affects cannot be explained through our essence, or [seu] nature, alone (by $3 \mathrm{~d} 1$ and $\mathrm{d} 2$ ), but must be defined by the power, that is (by 3p7), by the nature of external causes compared with our own'. But this identification has been established earlier in $4 \mathrm{~d} 8$, which provides the definition of virtue: 'By virtue and power I understand the same thing, that is (by 3p7), virtue, insofar as it is related to man, is the very essence, or nature, of man, insofar as he has the power of bringing about certain things, which can be understood through the laws of his nature alone.' (my emphasis)

${ }^{31}$ Excellent, recent treatments of this issue, both of whom center on Spinoza's theory of essences in order to explain the unique content of the highest kind of knowledge, are found in Don 
Nevertheless, it is demonstrable that understanding things intuitively means understanding the absolute necessity of things, or understanding things under a species of eternity: As Spinoza writes in $5 \mathrm{p} 23 \mathrm{~s}$, the idea which expresses the essence of the body under a species of eternity, whose understanding pertains to the essence of the mind, is necessarily eternal. This understanding is nothing but an adequate understanding of God (5pp24-27), and God's eternal necessity (which is synonymous with his essence, according to $1 \mathrm{~d} 8$ ). The intellectual love of God, the affect that accompanies this understanding, is indicative of the union between the subject and the object of affection, which is perhaps the most prominent feature of all kinds of love. In the case of passionate love, the lover wants to unite with the beloved, or at least possess them (or it); in the case of friendship, the basis of the union is a comprehension of shared properties and equality. In the case of the intellectual love of God, the joy that arises in the subject is a direct result of a unifying understanding between God and the mind. This is addressed directly in $5 \mathrm{p} 36$ :

The mind's intellectual love of God is the very love of God by which God loves himself, not insofar as he is infinite, but insofar as he can be explained by the human mind's essence, considered under a species of eternity; that is, the mind's intellectual love of God is part of the infinite love by which God loves himself. (my emphasis)

Garrett, "Spinoza's Theory of Scientia Intuitiva", in Necessity and Nature in Spinoza's Philosophy. Oxford: Oxford University Press, 2018; and Soyarslan (2016). 
Thus, Spinoza brings his connection between love and essence to its final iteration in the culmination of the Ethics. The highest goal of human life, the achievement of virtue and blessedness, is constituted in a love of God which is simultaneously a unification with him through understanding. By understanding oneself as a necessary part of Nature, under a species of eternity, the mind understands that it itself is a part of God or Nature; therefore, the love of God is actually God's love of himself, understood via the particular mind.

I will now address the issues that can be resolved through this interpretation. First, the debate regarding shared and unique essences can be redefined in a way that addresses the issue without recourse to the problematic actual-formal distinction. There is no shared, independent essence, but only expressions of unique essences, understood through their shared properties (which they have, insofar as they are an inseparable part of Nature and subject to necessary and determined natural laws). Each thing has an essence which is inalienable to it, and is expressed differently according to the aspect under which the thing is understood; and these different expressions are always objects of love.

This brings us to the ethical significance of Spinoza's notion of essence. A human's essence is nothing but their very nature; and that nature is best expressed through the things they love. A person is defined by what he or she loves; the money-lover is greedy, the friend is moral; and the philosopher is blessed and truly virtuous. The excellence of the object of love is a direct indication of the excellence of the lover ${ }^{32}$. Spinoza is claiming that if people understand

\footnotetext{
32 This idea is to be found in several Platonic dialogues; see, for example, Symposium 210-212, Lysis 205e-206a (in a rather interesting iteration), Phaedrus 252d-253c. It is specifically interesting to note the similarities between the presentation of
} 
better, they will love better things, and thus better themselves. Moreover, through this improvement of understanding and the increased stability of love and joy, people will be more moral and pious (in the philosophical, and not superstitious way, of course). To love the right things is to be a good, moral person; in the social context, loving the right object means loving your neighbour.

Last but not least, the debate over the possible destruction of essences may be a addressed. Insofar as anything can be conceived as destroyed, that is, under the aspect of duration, the essence is destroyed with the thing it defines. This is because the thing and its essence are both understood as destructible, under a species of duration. But insofar as the thing is conceived adequately, under a species of eternity, the essence is eternal. That is, the thing and its essence are one and the same, and when eternity conceivably pertains to the thing, its essence is conceivably eternal as well. There is no equivocation here, nor two kinds of essence (one destructible and one eternal), but the same thing perceived under different aspects.

\section{Conclusion}

The connection between love and essence (identified by Spinoza with desire) is ubiquitous in the Ethics, and it is also metaphysically and psychologically coherent. Analyzing the notion of essence through the prism of Spinoza's theory of love shows that essence can be expressed in different ways, and be reflected through different objects of love. These objects of love, in turn, signify the extent to which the

different kinds of lovers, their love-objects, and their philosophical development in Spinoza and Plato's Symposium.

Manuscrito - Rev. Int. Fil. Campinas, v. 44, n. 3, pp. 01-41, Jul.-Sep. 2021. 
affected mind understands itself, God and things in the world. Each object is a different expression of the same single, unique essence of the individual, and therefore of the desire which defines them. This interpretation allows to solve some puzzles about essence, and also to establish the importance of love in Spinoza's philosophy as a wholeopening the door for further studies concerning love and its role in different areas of study, such as Spinoza's theory of knowledge, his critique of orthodox religion, and more.

\section{References}

BENNET'T, J. A Study of Spinoza's Ethics. Indianapolis, IN: Hackett, 1984.

BICKNELL, J. "An Overlooked Aspect of Love in Spinoza's Ethics", Iyyun: The Jerusalem Philosophical Quarterly 47, 41-55, 1998.

CURLEY, E. Behind the Geometrical Method. Princeton: Princeton University Press, 1988.

The Complete Works of Spinoza. Princeton: Princeton University Press, 1985.

DELEUZE, G. Spinoza: Pracitcal Philosophy, translated by Robert Hurley, San Francisco: City Lights Books, 1988.

DELLA ROCCA, M. Spinoza. New York: Routledge, 2008.

"Spinoza's Metaphysical Psychology," in The Cambridge Companion to Spinoza, Don Garrett (ed.), Cambridge: Cambridge University Press, 1996(a).

Representation and the Mind-Body Problem in Spinoza, Oxford: Oxford University Press, 1996(b). 
GARBER, D. "Dr. Fischelson's Dilemma: Spinoza on Freedom and Sociability", in Spinoza on Reason and the "Free Man," ed. Yirmiyahu Yovel and Gideon Segal, New York: Little Room Press, 1994.

GARRETT, D. "Spinoza's Theory of Scientia Intuitiva", in Necessity and Nature in Spinoza's Philosophy. Oxford: Oxford University Press, 2018. (2009). "Spinoza on the Essence of the Human Body and the Part of the Mind That is Eternal", in $A$ Cambridge Companion to Spinoza's Ethics, ed. by Olli Koistinen, Cambridge: Cambridge University Press.

HÜBNER, K. "Spinoza on Essences, Universals, and Beings of Reason". Pacific Philosophical Quarterly, 97(1), 58-88, 2015.

JAMES, S. "Spinoza the Stoic," in The Rise of Modern Philosophy, Tom Sorell (ed.), Oxford: Clarendon Press, 1993.

JARRETT, C. “Spinoza's Distinction between Essence and Existence", Iyyun 50, 2001.

KISNER, M. "Reconsidering Spinoza's Free Man: The Model of Human Nature", Oxford Studies in Early Modern Philosophy (5), 2010.

KRAUT, R. Aristotle on the Human Good, Princeton: Princeton University Press, 1991.

LÆRKE, M. "Aspects of Spinoza's Theory of Essence: Formal essence, non-existence, and two types of actuality". In The Actual and the Possible : Modality and Metaphysics in Modern Philosophy, ed. by Mark Sinclair. Oxford: Oxford University Press, 2017. 
LEBUFFE, M. "The Anatomy of the Passions," in The Cambridge Companion to Spinoza's, Ethics, Olli Koistinen (ed.), Cambridge: Cambridge University Press, 2009.

LUCASH, F. "Spinoza on Friendship", Philosophia 40 (2), 2012.

MARSHALL, C. "Spinoza on Destroying Passions with Reason." Philosophy and Phenomenological Research 85 (1), 139-60, 2012.

MARSHALL, E. The Spiritual Automaton: Spinoza's Science of the Mind. Oxford, United Kingdom: Oxford University Press, 2013.

MARTIN, C.P. The Framework of Essences in Spinoza's Ethics. British Journal for the History of Philosophy, 16 (3), 489-509, 2008.

NADLER, S. "On Spinoza's 'Free Man'", Journal of the American Philosophical Association, vol 1 (1), 2015.

RORTY, A. O. "Spinoza on the Pathos of Idolatrous Love and the Hilarity of True Love" in Feminist Interpretations of Benedict Spinoza, edited by Moira Gatens, 65-85. University Park, Pa.: Pennsylvania State University Press, 2009.

SHARP, H. "Love and Possession: Towards a Political Economy of Ethics 5", NASS Monograph 14 (2009): 119.

SOYARSLAN, S. "The Distinction between Reason and Intuitive Knowledge in Spinoza's Ethics." European Journal of Philosophy 24 (1), 27-54, 2016.

VILJANEN, V. "Spinoza's Essentialist Model of Causation". Inquiry, 51(4), 412-437, 2008. 
YAKIRA, E. Spinoza: The Case for Philosophy. Cambridge: Cambridge University Press, 2015.

YOUPA, A. The Ethics of Joy: Spinoza on the Empowered Life. Oxford: Oxford University Press, 2020.

"Spinoza's Model of Human Nature", Journal of the History of Philosophy, vol. 48 (1), 2010.

$(c c)$ BY

Manuscrito - Rev. Int. Fil. Campinas, v. 44, n. 3, pp. 01-41, Jul.-Sep. 2021. 